\title{
Investment and Expenditure on Innovation Activities and Innovative Capability: Empirical Evidence from Portuguese Services Firms and KIBS
}

\author{
Maria Jose Madeira Silva (Corresponding author) \\ University of Beira Interior and CIEO \\ Research Centre for Spatial and Organizational Dynamics \\ Pólo IV, 6200-209 Covilhã, Portugal \\ Tel: 35-127-531-9651 E-mail: msilva@ubi.pt \\ Jorge Simões \\ Polytechnic Institute of Tomar and GOVCOPP \\ Research Unit in Governance, Competitiveness and Public Policy \\ Quinta do Contador, 2300-313 Tomar, Portugal \\ E-mail: jorgesimoes@ipt.pt \\ Jacinta Moreira \\ Polytechnic Institute of Leiria and GOVCOPP \\ Research Unit in Governance, Competitiveness and Public Policy \\ Campus 2, 2411-901 Leiria, Portugal \\ E-mail: jacinta.moreira@estg.ipleiria.pt \\ Gastão Sousa \\ Maia Institute of Higher Education and GOVCOPP \\ Research Unit in Governance, Competitiveness and Public Policy \\ Av. Carlos Oliveira Campos, 4475-690 Avioso S. Pedro, Portugal \\ E-mail: gsousa@docentes.ismai.pt
}

Received: November 14, 2011

Accepted: December 8, 2011

Published: February 1, 2012

doi:10.5539/ibr.v5n2p114

URL: http://dx.doi.org/10.5539/ibr.v5n2p114

Presented at the Regional Studies Association Research Network Seminar Series: Policy Implications for knowledge Intensive Business Services (KIBS) and Innovation in Regions in a Globalised Economy (October 2011)

\begin{abstract}
This research aims to analyze the degree of importance of investment and expenditure on innovation activities for entrepreneurial innovative capability, in the scope of Portuguese services firms and the firms belonging to the KIBS - knowledge-intensive business services. A conceptual model was proposed and several research hypotheses were empirically tested using secondary data, belonging to the 5th CIS 2006, supervised by EUROSTAT. A data set from 829 KIBS firms was studied. The method used will be the logistic regression model. According to the results obtained, the greater the financial investment in acquisition of machinery, equipment and software, in internal research and development, in acquisition of external knowledge, in marketing activities and other procedures, the greater the propensity for firms to innovate in terms of services. This study highlights the contributions that innovation activities can provide in what regards the development of innovation process, giving special emphasis to their service innovation.
\end{abstract}


Keywords: Innovation, KIBS, Services, Innovative Capability, CIS

\section{Introduction}

The growing tendency of globalization and interdependency of economies is inferred in highly competitive and chaotic context for the firm. In this sense, it is of major relevance to analyse the determinant factors of innovative capability of firms in general and of service firms in particular, due to the great importance that these firms present in the economy of the countries. In fact, in the last decades there has been an evolution of the role of the services sector in the economy, not only due to the importance of this sector assumes in innovation, but also in the competitiveness, in job creation and in the economic growth (Hauknes, 1998; de Jong, Bruins, Dolfsma \& Meijaard, 2003; Howells \& Tether, 2004). A study carried out by The European Union regarding 25 countries, corroborates these facts since, in 2004, services sector firms, in average contribute 39,9\% towards total employment and for $46,2 \%$ of value added (Arundel, Kanerva, Cruysen \& Hollanders, 2007).

Taking in account the role carried out by the countries' service firms, the fact that some of these firms present a tendency towards innovation is becoming increasingly important since it is a fundamental competitive advantage in the sector (Tether, 2005). In such way, it is necessary to understand, among the innumerable factors that influence the innovative character of a service organization, which are the real relevant factors when stimulating the innovative capacity of a service firm, with the intention of adequately mobilizing the firms of the sector that seek innovation as a competitive advantage.

Gallouj (2002) stated that the studies which approach innovation in service firms suggest several factors that influence the innovative capacity of this type of firm. However, so that organizational actions and public policies are efficient, it is necessary to reduce the amount of factors to a set that actually represents a stimulus towards the innovative capacity of a service firm. But, among the innumerable factors, which are truly relevant?

Therefore, the aim of the present study is to identify, amongst a set of internal and external factors, those that influence the innovative capacity of service firms, namely: investments in innovation, entrepreneurial dimension, sector of activity, internationalization, external sources of information and the capacity to establish relationships and partnerships.

The present study aims to analyse the importance of the determinant internal and external factors of innovation capability of services firms. Factors previously analysed in other studies (Silva, 2003; Silva \& Leitão, 2009), present a significant impact in the innovative capability in the sector of industrial firms however, at services level there is a need to identify and analyse which factors really stimulate or restrain entrepreneurial innovative capability.

This study has as reference the innovation in services approach, the services innovation approach and the reference approach regarding the innovation topic, where the systemic approach of innovation and the network and intraorganizational approach is emphasized. Considering this conceptual frame, hypotheses were formulated to test and analyse factors that limit the activity and the innovative performance of Portuguese services firms.

To empirically test the formulated hypothesis, secondary data provided by "OCES- Observatório da Ciência e do Ensino Superior" (Higher Education and Sciences Observatory), belonging to - Community Innovation Survey (CIS 2006) were used. This questionnaire was implemented under the supervision of EUROSTAT. The general linear regression model, namely the logistic regression model is applied.

The study is structured as follows: section two, provides relevant literature about the topic of innovation in services, a conceptual model is proposed and are formulated the hypotheses to be empirically tested in the statistical model. Section three defines the sample, the variables used in the empirical study are described and characterized and finally the logistic regression model is presented. In section four, the obtained results are discussed in the scope of the literature considered relevant. In the last section, the main concluding remarks as well as guidelines for futures research are presented.

\section{Innovation in Services}

According to Miles (2001), the literature about services has registered an intense evolution since the 60s. There has been a growing interest in the study of innovation in services. This is due to the fact that the service sector presents an above average growth (Segal-Horn, 2006; Sundbo, 2009), which concerns new firms, job creation and, still, the contribution of these firms towards development and generation of wealth for the region and countries. The service sector covers a wide range of activities with differing characteristics (Hauknes, 1998; Drejer, 2004; Hipp \& Grupp, 2005; Miles, 2005; Vries, 2006). Sectors such as information technology, finance, transports and communication have been of major importance in the internal product of nations, either in developed countries or, in developing countries (Camacho \& Rodriguez, 2005). 
According to the Oslo Manual (OCDE, 2005), innovation in services is organized in a less formal way, it is less technological and is more incremental in nature. Sundbo \& Gallouj $(1998,2000)$ divided the innovation in services into five categories: product innovation (a new product or new service which, when sold, involves service supply); process innovation (change in one or more procedures to produce or provide a service); organizational innovation (new form of management and organization); market (market changes such as, the discovery of previously non-existing segment ad hoc innovation (search of a solution towards a certain problem presented by a client).

Gallouj \& Weinstein (1997) noticed that it is difficult to analyse innovation in the service sector due to two reasons, firstly, because innovation theories were developed under the scope of the study of technological innovation, in industrial firms and secondly because it is not easy to measure and detect changes in services, due to specific characteristics of their activities. The literature revision in the scope of innovation in service embraces three fundamental approaches: assimilation, demarcation and synthesis. (Haukens, 1998; Gallouj, 1998; Sundbo \& Gallouj, 1998; Freeman \& Louçã, 2001; Coombs \& Miles, 2000; Howells, 2000, 2001; Gallouj, 2002; Howells, 2003; Howells \& Tether, 2004; Drejer, 2004; Miles, 2005; Vries, 2006).

Studies with an assimilation/technologists approach view services from a manufacturing perspective. These studies are the most numerous and tend to focus on the impact of technology on services (Barras, 1986, 1990; Gallouj, 1998; Freeman \& Louçã, 2001; Gallouj, 2002). Studies demarcation/ services-oriented approach start from the notion that services are distinctly different from manufacturing and that service innovation has features that requires new theories (Gallouj and Weinstein, 1997; Sundbo \& Gallouj, 1998; Coombs \& Miles, 2000) Studies synthesis/ integrative approach recognized that services innovation focuses attention on hitherto neglected elements of innovation, which are relevant to booth service and manufacturing (Coombs and Miles, 2000; Drejer, 2004; Miles, 2005; Vries, 2006).

These approaches show that innovation in services differs from innovation in products. According to Sundbo (1997) and Tether \& Hipp (2002), the specific characteristics of services (intangibility, heterogeneity, perishability and simultaneously of production and consumption) differentiate them from physical products, bring difficulties and restrictions to imports of programs and management models related to innovation in the industrial sector. Such services have special features that require specific innovative models for the sector; somewhat still scarce in the literature (Barras 1986, 1990; Edgett, 1993; Gallouj, 1998, 2002; Pires, Sarkar \& Carvalho, 2008).

Despite the absence felt by the researchers, during the last years, some studies show that the innovation in services leads towards a greater level of growth and dynamism of the economic activity (Sundbo, 1997; De Brentani, 2001). This is due to the entry barriers relatively low, the higher possibility of intangibility, and of achieving sustainable competitive advantages, such as it happens with physical goods (de Jong \& Vermeulen, 2003; Oke, 2007; Toinonen \& Tuominen, 2009).

During the last two decades, the deregulation and globalization of markets, as well as internationalization of service firms, originated severe competition between these firms (Elche e González, 2008). These trends set innovation in services in the heart, as a means of constant adaptation to a turbulent environment, which requires a continuous stream of new market offers (Stevens \& Dimitriadis, 2005; Djellal \& Gallouj, 2008).

The capability for innovating, at the level of services, is entitled entrepreneurial innovative capability. Therefore, the term entrepreneurial innovative capability was used in this study to integrate the several components that result from the innovative process of the services firm, namely service innovation, process innovation, organizational innovation and marketing innovation (OCDE, 2005). The study of entrepreneurial innovative capability at the services level is of major concern here. Thus the firm is considered innovative if "it introduced new or technologically improved service during 2004-2006" (CIS 2006, 3).

It is important to emphasize that the innovative capability varies from firm to firm and it is determined by a vast and complex number of factors, both propelling and confining of the innovative entrepreneurial process. The explanatory factors of innovation are not all considered in the factors referred here. However, there is an intention to analyse the process of innovation at an entrepreneurial level, considering the literature review of this study, the following factors are analysed: investment in innovation, regarding the formulation of research hypothesis is subsequently discussed.

The importance of investment and expenditure on innovation, within the firm, such as acquisition of machinery, equipment, software and external knowledge, is demonstrated in the studies of Mansfield (1988), Shields \& Young (1994), Archibugi, Evangelista \& Simonetti (1995), Weiss (2003), Camacho \& Rodriguez (2005), Canopa \& Stoneman (2008) and Elche \& González (2008). According to these authors, the firms that make large investments in research and development, in improvement of structures and collaborator's skills, acquire a higher technological capability and consequently, have the capacity to produce more innovations. These authors argue that firms which 
invest in better structures, technology and qualified staff indicate higher innovative capability. Thus, the following relation between investment and expenditure on innovation and the entrepreneurial innovative capability:

Hypothesis 1: investment and expenditure on innovation activities is positively related to service firms' propensity to innovate in terms of products/ services

Based on the generic hypothesis related to investment and expenditure on innovation activities and to the typology presented in the Innovation Survey CIS 2006, the following seven specific hypotheses are formulated in this context:

H11: Carrying out internal $R \& D$ activities is positively related to service firms' propensity to innovate in terms of products/services.

H12: Carrying out external activities of $R \& D$ is positively related to service firms' propensity to innovate in terms of products/services.

H13: Acquisition of machinery, equipment and software is positively related to service firms' propensity to innovate in terms of products/services.

H14: Acquisition of other external knowledge is positively related to service firms' propensity to innovate in terms of products/services.

H15: Carrying out training is positively related to service firms' propensity to innovate in terms of products/services.

H16: Carrying out marketing activities is positively related to service firms' propensity to innovate in terms of products/services.

H17: Investment and expenditure in other procedures is positively related to service firms' propensity to innovate in terms of products/services.

\section{Design Research}

\subsection{Data Presentation: Population and Sample}

The data used in this research, are secondary data, collected through a survey that consisted in a questionnaire named as Community Innovation Survey 2006 - CIS 2006 between June and November 2005. In Portugal, the survey was conducted by OCES - Observatório da Ciência e do Ensino Superior (Higher Education and Sciences Observatory), in collaboration with INE - Instituto Nacional de Estatística (National Institute of Statistics), and concerning innovative activities of Portuguese companies during the period of 2002 to 2004.

The population contemplates all the services firms according to the classification of economic activities CAE - Rev. 2.1. (CAE, 2003). The initial sample was built by INE, according to EUROSTAT'S methodological specifications, and extracted from a population of 23348 firms registered in FUE - Ficheiro de Unidades Estatísticas do INE (File of Statistical Unit of NSI). An initial sample of 7730 firms was withdrawn from this population, which later was corrected to 6482 firms. Regarding the considered sample, 4815 firms replied to the questionnaire, therefore a $74.3 \%$ response rate (OCES, 2006). From the firms of the sample, only 809 firms belonging to the services sector, more are considered (Table 1).

Insert Table 1 Here

Thus, the firms of the KIBS sector will be considered as innovative in the services, if they introduce new or technologically improved services during the period 2002-2004.

\subsection{Description and Data Characterization}

In this study, the innovative capability is measured from the information collected at the level of service innovation, being considered as the dependent variable. This dimension is presented as a dichotomy variable binary-data based which adopts value 0 if the firm did not innovate and value 1 for those that innovated. With regard to these independent variables, they are represented in Table 2, summarizing variables and measures used for each factor operationalization of the model and later used to empirically test the formulated hypothesis in the proposed conceptual model (Table 2).

Insert Table 2 Here

\subsection{Method: Logistic Regression Model}

From the theoretical literature review and the proposed conceptual model, it was verified that the innovative capability of the firm is a complex phenomenon influenced by a wide range of factors. Since it is necessary to explore the relationship between these factors and the innovative capability, there is an intention to study, more 
specifically, the statistical relationship of a dependent variable in relation to more than one explanatory variable; it was decided to use the Logistic Regression Model (Logit Model). In the dimension of the Innovative capability of the services, there is a correspondent regression model where the variable dependent is dichotomic, so according (Hair Jr., Babin, Money \& Samouel, 2003) the adequate application model is the Logit regression model. This model, has been the most widely used in the empirical studies carried out (Silva, 2003), and is being presented as an appropriate analytical technique for $\mathrm{t}$ conceptual models proposed, since these include a dependent categorical variable (binary or dichotomic) and several independent variables, see table 2.

\section{Data Analysis}

In this research stage, logistic regression models were applied to the Community Innovation Survey, testing the proposed model. Wald statistic was used as the testing statistics to analyse the behavior of variables and the adjustment quality of the proposed model. The logistic regression results for the KIBS Innovation Model are presented in table 3 (Table 3 ).

Insert Table 3 Here

The logistic regression results for the model (table 3) show that not all regression parameter estimates are statistically significant at a level of 5\%. Regarding adjustment quality of the model, the results show that the predictive capability of the model is of $85.6 \%$, which result from the comparison between the values of the variable response values predicted by the model and those observed. The Chi-square statistic test has a value of 540.72 with proof value less than the significance level of 0.05 . The log-likelihood statistics, with a value of 455.75 , corroborates the global significance of the model.

Considering the hypothesis formulated it was possible to identify the existence of two no supported hypothesis. The hypothesis H12, regarding external activities of $\mathrm{R} \& \mathrm{D}$, did not present statistical significance to the level of 0.05 .

The hypothesis H14, is not supported at a significant level of 0.05 . The results don't permit to conclude about the impact the Acquisition of other external knowledge have on innovation propensity of firms innovating at the product/services level.

Concerning the generic hypothesis H1, which aimed to test the effects of investment in innovation on innovative propensity in terms of product/services, a positive relationship with significance under 0.05 was found when a service firm makes investment in internal investigation and development activities (variable Adi1), acquisition of machinery, equipment and software (Adi3), Training (Adi5), in marketing activities (Adi6), and other procedures (Adi7), it presents a greater propensity to innovate in terms of services. Considering the results obtained and those presented in column Exp (B), it is observed that by investing in the training (8.734), and internal investment in innovation (4.105), as well as implementing marketing activities (2.731), and acquisition of machinery, equipment and software (2.397) and also other procedures for developing new products (1.855), service firms are seen to be more likely to innovate in terms of services. From the significance of the values obtained, the results show that investments in training and internal investment in innovation are those which stimulate the propensity for KIBS firms to innovate most.

\section{Conclusions and Recommendations}

The aim of this study was to analyze the degree of importance of investment and expenditure on innovation activities for entrepreneurial innovative capability, in the scope of Portuguese services firms and the firms belonging to the KIBS - knowledge-intensive business services. With the purpose of improving comprehension of innovation in services and identifying the main determinants of innovation in the service sector in the area of innovation activities, various hypotheses for investigation were formulated based on the literature review carried out of innovation in product/services. The literature review identified three fundamental approaches in the sphere of service innovation: assimilation, demarcation and synthesis.

This investigation highlights seven factors stimulating and limiting innovative capability in firm: Intramural (in-house) R\&D; Extramural R\&D; Acquisition of machinery, equipment and software; Acquisition of other external knowledge; Training; Adi6= Marketing activities; Other procedures. investment in innovation activities. It was in relation to these factors that the various hypotheses tested empirically were formulated.

According to the results obtained, some investments in innovation present positive and significant effects in service innovation; therefore, the greater the financial investment in acquisition of machinery, equipment and software, in internal research and development, in training, in marketing activities and other procedures, the greater the propensity for firms to innovate in terms of product/services. The analysis of the results obtained in the statistical analysis allows pointing out that, considering hypothesis, in the KIBS companies, it is possible to bear that innovation is rather a result of internal processes than the acquisition of external resources, this is due to internal 
characteristic of the service.

The principle contribution of this research lies in inclusion in the study of factors determining the innovative capability of service firms, seeking to increase comprehension of innovation in services and identify the main factors stimulating innovation in this sector. The investigation proposed an empirical study based on a logit model, for joint analysis that provided measurement of the direct and indirect effects of a selected set of explanatory variables of the innovative capability of KIBS Portuguese companies.

The main limitations of this study arise from the limited data obtained, through lack of access to all the results of CIS 2006, for example, the number of employees per company. Nor was it possible to draw up a comparison of results, with previous CIS, so as to assess evolutionary tendencies in the area of innovation activities and expenditure.

To continue this investigation, in future work it is proposed to repeat the empirical study with data from other European countries where the Community Innovation Survey 2006- CIS 2006 was carried out. In addition, a new study will be developed with the proposed conceptual model, with the aim of contrasting empirically data from the Community Innovation Survey 2008 - CIS 2008. From this perspective, it is considered that repetition of the investigation in Europe, more precisely in countries that responded to the same questionnaires, could also enrich study of the phenomenon of entrepreneurial innovation, and specifically the approach to service sector innovation.

\section{Acknowledgements}

This article was partially funded by Foundation for Science and Technology

\section{References}

Archibugi, D., Evangelista, R., \& Simonetti, R. (1995). Concentration, firm size and innovation: evidence from innovation costs. Technovation, 15(3), 153-164. http://dx.doi.org/10.1016/0166-4972(95)96616-2

Arundel, A., Kanerva, M., Cruysen, A., \& Hollanders, H. (2007). Innovation statistics for the European service sector, INNO Metrics report, Brussels: European Commission, DG Enterprise.

Barras, R. (1986). Towards a theory of innovation in services. Research Policy, 15(1), 161-173. http://dx.doi.org/10.1016/0048-7333(86)90012-0

Barras, R. (1990). Interactive innovation in financial and business services: The vanguard of the service revolution. Research Policy, 19(1), 215-237. http://dx.doi.org/10.1016/0048-7333(90)90037-7

CAE - Rev. 2.1 (2003). Classification of economic activities - rev. 2.1, Law no 197, 27 August

Camacho, J., \& Rodríguez, M. (2005). How innovative are services? An empirical analysis for Spain. The Service Industries Journal, 25(2), 253-271. http://dx.doi.org/10.1080/0264206042000305448

Canepa, A., \& Stoneman, P. (2008). Financial constraints to innovation in the UK: evidence from CIS2 and CIS3. Oxford Economic Papers, 60(4), 711-731. http://dx.doi.org/10.1093/oep/gpm044

CIS 2006. (2007). Community Innovation Survey 4, Center for Science and Higher Education, Ministry of Science and Technology, Lisboa, Portugal.

Coombs, R., \& Miles, I. (2000), 'Innovation, measurement and services: the new problematic', in JS Metcalfe and I. Miles (eds). Innovation Systems in the Service Economy: Measurement and Case Study Analysis, Boston, MA: Kluwer Academy Publisher, EUA. http://dx.doi.org/doi: 10.1016/S0148- 2963(01)00259-4.

De Brentani, U. (2001). Innovative versus incremental new business services: different keys for achieving success. Journal of Product Innovation Management, 18(1), 169-87. http://dx.doi.org/10.1016/S0737-6782(01)00071-6

De Jong, J., \& Vermeulen, P. (2003). Organizing successful new service development: a literature review. Management Decision, 41(9), 844-858. http://dx.doi.org/10.1108/00251740310491706

De Jong, J., Bruins, A., Dolfsma, W., \& Meijaard, J. (2003). Innovation in services firms explored: what, how and why?. EIM, Business and Policy Research, Zoetermeer.

Djellal, F., \& Gallouj, F. (2007). Innovation and employment effects in services: a review of the literature and an agenda for research. The Service Industries Journal, 27(3), 193-214. http://dx.doi.org/10.1080/02642060701206959

Drejer, I. (2004). Identifying innovation in surveys of services: a schumpeterian perspective. Research Policy, 33(2), 551-562. http://dx.doi.org/10.1016/j.respol.2003.07.004

Edgett, S. (1993). Developing new financial services within U.K. building societies. International Journal of Bank Marketing, 11(3), 35-43. http://dx.doi.org/10.1108/02652329310027701 
Elche, D., \& González, Á. (2008). Influence of innovation on performance: analysis of Spanish service firms. The Service Industries Journal, 28(10), 1483-1499. http://dx.doi.org/10.1080/02642060802250294

Gallouj, F. (1998). Innovation in reverse: services and the reverse product cycle, Topical Paper, SI4S, Oslo: STEP Group

Gallouj, F. (2002). Innovation in services and the attendant old and new myths. Journal of Socio-Economis, 31(1), 137-154. http://dx.doi.org/10.1016/S1053-5357(01)00126-3

Gallouj, F., \& Weinstein, O. (1997). Innovation in services. Research Policy, 26(3), 537-556. http://dx.doi.org/10.1016/S0048-7333(97)00030-9

Hair Jr., J. F., Babin, B., Money, A. H., \& Samouel, P. (2003). Essentials of business research methods. New Jersey: John Wiley \& Sons

Hauknes, J. (1998). Services in innovation, innovation in services, Synthesis Report, $n^{\circ} 1$, SI4S, Oslo: STEP Group

Hipp, C., \& Grupp, H. (2005). Innovation in the service sector: the demand for service-specific innovation measurement concepts and typologies. Research Policy, 34(3), 517-535. http://dx.doi.org/10.1016/j.respol.2005.03.002

Howells, J. (2000). Innovation \& services: new conceptual frameworks. CRIC Discussion Paper, $\mathrm{n}^{\mathrm{o}} 38$, CRIC, Manchester, UK

Howells, J. (2001). The nature of innovation in services. Innovation and Productivity in Services, OCDE, Paris, French, 55-79.

Howells, J. (2003). Innovation and services: the combinatorial role of services in the knowledge-based economy. International Conference on New Trends and Challenges of Science and Technological Innovation in a Critical Era, Taipei.

Howells, J., \& Tether, B. (2004). Innovation in services: issues at stake and trends, Final Report, Commission of the European Communities, Brussels-Luxembourg.

Mansfield, E. (1988). The speed and cost of industrial innovation in Japan and the United States: external vs. internal technology. Management Science, 34(10), 1157-1168. http://dx.doi.org/10.1287/mnsc.34.10.1157

Miles, I. (2001). Services innovation: a reconfiguration of innovation studies. The University of Manchester (Discussion Paper Series), Manchester, UK.

Miles, I. (2005). Innovation in services, in Fagerberg, J., Mowery, R. and Nelson, R. (Ed.). The Oxford handbook of innovation, Oxford: Oxford University 433-458. http://dx.doi.org/10.1093/oxfordhb/9780199286805.001.0001

OCDE. (2005). OSLO manual: proposed guidelines for collecting and interpreting technological innovation data, 3rd edition, Paris, French

OCES. (2006). Ministry Science and Technology, Center of Science and Higher Education, Summary Table of Results $4^{\circ}$ Community Innovation Survey in Portugal, Lisbon.

Oke, A. (2007). Innovation types and innovation management practices in service companies. International Journal of Operations \& Production Management, 27(6), 564-587. http://dx.doi.org/10.1108/01443570710750268

Pires, C., Sarkar, S., \& Carvalho, L. (2008). Innovation in services: how different from manufacturing?. The Service Industries Journal, 28(10), 1339-1356. http://dx.doi.org/10.1080/02642060802317812

Segal-Horn, S. (2006). Strategy in service organizations, in Faukner, D. \& Campbell, A. (Ed.). Strategy: a strategy overview and competitive strategy, Oxford, UK: University press, 472-506.

Shields, M., \& Young, S. (1994). Managing innovation costs: a study of cost consciousness behavior by R\&D professionals. Journal of Management Accounting Research, 6, 175-189.

Silva, M. (2003). Determinants factors of Entrepreneurial Innovation Capability of Industrial Firms in Portugal, Ph.D. Thesis in Management, University of Beira Interior, Covilhã.

Silva, M., \& Leitão, J. (2009). Reinforcing the entrepreneurial innovation capacity of industrial SMES with networks, in Leitão, J. \& Baptista, R. (Ed.). Public policies for fostering entrepreneurship: an European perspective, International Studies in Entrepreneurship, Vol. 22, Springer 1. http://dx.doi.org/10.1007/978-1-4410-0249-8_6.

Slater, S., \& Narver, J. (1994). Market orientation, customer value, and superior performance. Business Horizons, 37 , 22-28. http://dx.doi.org/10.1016/0007-6813(94)90029-9 
Stevens, E., \& Dimitriadis, S. (2005) Managing the new service development process: towards a systemic model. European Journal of Marketing, 39(1/2), 175-198. http://dx.doi.org/10.1108/03090560510572070

Sundbo, J. (1997). Management of innovation in services. The Service Industries Journal, 17(3), 432-445. http://dx.doi.org/10.1080/02642069700000028

Sundbo, J. (2009). Innovation in the experience economy: a taxonomy of innovation organizations. The Service Industries Journal, 29(4), 431-455. http://dx.doi.org/10.1080/02642060802283139

Sundbo, J., \& Gallouj, F. (1998). Innovation in services, SI4S Synthesis Papers, Oslo: STEP Group.

Sundbo, J. \& Gallouj, F. (2000). Innovation as a loosely coupled system in services. International Journal of Services Technology and Management, 12(1), 15-36. http://dx.doi.org/10.1504/IJSTM.2000.001565

Tether, B. (2005). Do Services Innovate (Differently)? Insights from the European Innobarometer Survey. Industry and Innovation, 12, 153-184. http://dx.doi.org/10.1080/13662710500087891

Vries, E. (2006). Innovation in services in networks of organizations and in the distribution of services. Research Policy, 35(5), 1037-1051. http://dx.doi.org/10.1016/j.respol.2006.05.006

Weiss, P. (2003). Adoption of product and process innovations in differentiated markets: the impact of competition.

Review of Industrial Organization, 23, 301-314. http://dx.doi.org/10.1023/B:REIO.0000031372.79077.fc

Table 1. Classification of Services

\begin{tabular}{|c|c|c|c|}
\hline Services typology & Activity services sector & NACE Codes & $\mathrm{N}$ \\
\hline \multirow{3}{*}{$\begin{array}{l}\text { KIBS } \\
\text { knowledge-intensive } \\
\text { business services }\end{array}$} & $\begin{array}{l}\text { Computer and related activities } \\
\text { Research and Development }\end{array}$ & $72-73$ & 140 \\
\hline & $\begin{array}{l}\text { Architectural and engineering activities } \\
\text { Technical testing and analysis }\end{array}$ & 74 & 689 \\
\hline & Total & & 829 \\
\hline
\end{tabular}

Table 2. Variables of Model

\begin{tabular}{|l|l|l|l|}
\hline Variables & Code & Measures & Codification \\
\hline Innovation Product and Services & In & $\begin{array}{l}\text { 1= firms innovated in product/services } \\
0=\text { firms did not innovated in product/services }\end{array}$ & Dichotomy \\
\hline Investments in Innovation & Adi & $\begin{array}{l}\text { Investment and Expenditures in Innovation Activities: } \\
\text { Intramural (in-house) R\&D (Adi1) }\end{array}$ & $\begin{array}{l}\text { Binary: } \\
1=\text { engage innovation activities } \\
\end{array}$ \\
& & Extramural R\&D (Adi2) & $0=$ not engage \\
& & Acquisition of machinery, equipment and software (Adi3) & \\
& Acquisition of other external knowledge (Adi4) & \\
& Training (Adi5) & \\
& & Marketing activities (Adi6) & \\
& & Other preparations (Adi7) & \\
\hline
\end{tabular}


Table 3. Logit Regression Model Results for Services Innovation

\begin{tabular}{|l|l|l|l|l|l|}
\hline Model & $\begin{array}{l}\text { Parameter } \\
\text { Estimator }\end{array}$ & S.E. & Wald & Significance & XP(B) \\
\hline Innovation investments & & & & & \\
\hline - Intramural (in-house) R\&D (Adi1) & 1.412 & 0.274 & 26.489 & 0.000 & 4.105 \\
\hline - Extramural R\&D (Adi2) & -0.310 & 0.317 & 0.955 & 0.328 & 0.733 \\
\hline - Acquisition of machinery, equipment and software (Adi3) & 0.874 & 0.330 & 7.023 & 0.008 & 2.397 \\
\hline - Acquisition of other external knowledge (Adi4) & 0.355 & 0.229 & 1.409 & 0.235 & 1.426 \\
\hline - Training (Adi5) & 2.167 & 0.330 & 43.131 & 0.000 & 8.734 \\
\hline - Marketing activities (Adi6) & 1.0053 & 0.287 & 12.260 & 0.000 & 2.731 \\
\hline - Other preparations (Adi7) & 0.618 & 0.292 & 4.467 & 0.000 & 1.855 \\
\hline Constant & -3.455 & 0.243 & 21.888 & 0.000 & 0.032 \\
\hline Model Summary & & & & & \\
\hline Correct Predict (\%) & $85.6 \%$ & & & & \\
\hline Qui-square & 540.72 & & & 0.000 & \\
\hline Log likelihood & 455.75 & & & & \\
\hline Number of cases & 809 & & & & \\
\hline
\end{tabular}

